\title{
Article \\ Adropin Slightly Modulates Lipolysis, Lipogenesis and Expression of Adipokines but Not Glucose Uptake in Rodent Adipocytes
}

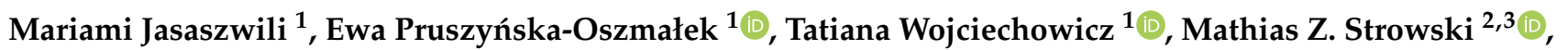 \\ Krzysztof W. Nowak ${ }^{1}$ (D) and Marek Skrzypski ${ }^{1, *(D)}$ \\ 1 Department of Animal Physiology, Biochemistry and Biostructure, Poznan University of Life Sciences, \\ 60-637 Poznan, Poland; mariami.jasaszwili@up.poznan.pl (M.J.); ewa.pruszynska@up.poznan.pl (E.P.-O.); \\ tatiana.wojciechowicz@up.poznan.pl (T.W.); kwnowak@up.poznan.pl (K.W.N.) \\ 2 Department of Hepatology and Gastroenterology, Charité-University Medicine Berlin, 13353 Berlin, Germany; \\ mathias.strowski@charite.de \\ 3 Department of Internal Medicine-Gastroenterology \& Oncology, Park-Klinik Weissensee, \\ 13086 Berlin, Germany \\ * Correspondence: marek.skrzypski@up.poznan.pl; Tel.: +48-618-486-137; Fax: +48-618-487-197
}

\section{check for}

updates

Citation: Jasaszwili, M.; Pruszyńska-Oszmałek, E.;

Wojciechowicz, T.; Strowski, M.Z.; Nowak, K.W.; Skrzypski, M. Adropin Slightly Modulates Lipolysis, Lipogenesis and Expression of Adipokines but Not Glucose Uptake in Rodent Adipocytes. Genes 2021, 12 914. https://doi.org/10.3390/ genes12060914

Academic Editor: Kumiko Ui-Tei

Received: 19 April 2021

Accepted: 11 June 2021

Published: 13 June 2021

Publisher's Note: MDPI stays neutral with regard to jurisdictional claims in published maps and institutional affiliations.

Copyright: (C) 2021 by the authors. Licensee MDPI, Basel, Switzerland. This article is an open access article distributed under the terms and conditions of the Creative Commons Attribution (CC BY) license (https:/ / creativecommons.org/licenses/by/ $4.0 /)$.

\begin{abstract}
Adropin is a peptide hormone which modulates energy homeostasis and metabolism In animals with diet-induced obesity, adropin attenuates adiposity and improves lipid and glucose homeostasis. Adropin promotes the proliferation of rodent white preadipocytes and suppresses their differentiation into adipocytes. By contrast, the effects of adropin on mature white adipocytes are unknown. Therefore, we aimed to evaluate the effects of adropin on lipolysis, lipogenesis and glucose uptake in white rodent adipocytes. We assessed the effects of adropin on the mRNA expression of adiponectin, resistin and visfatin. White preadipocytes were isolated from male Wistar rats. Differentiated 3T3-L1 cells were used as a surrogate model of white adipocytes. Lipolysis was measured by the evaluation of glycerol and free fatty acid secretion using colorimetric kits. The effects of adropin on lipogenesis and glucose uptake were measured using radioactive-labelled glucose. The expression of adipokine mRNA was studied using real-time PCR. Our results show that adropin slightly promotes lipolysis in rat adipocytes and 3T3-L1 cells. Adropin suppresses lipogenesis in rat adipocytes without influencing glucose uptake. In addition, adropin stimulates adiponectin mRNA expression and suppresses the expression of resistin and visfatin. These results indicate that adropin may be involved in controlling lipid metabolism and adipokine expression in white rodent adipocytes.
\end{abstract}

Keywords: adipocytes; adropin; 3T3-L1; lipolysis; lipogenesis; glucose uptake; adipokines

\section{Introduction}

Adropin is a peptide hormone encoded by energy homeostasis-associated (Enho), which was originally identified in 2008 by Kumar et al. [1]. The amino acid sequence of secreted adropin contains 43 amino acids and is produced by the proteolytic cleavage of 76 amino acid precursor. The amino acid sequence of adropin is identical to that in rats, mice, humans and pigs [1]. Enho mRNA is highly expressed in the brain and liver [1]; however, the presence of Enho mRNA and/or adropin peptide was also detected in the kidneys, heart and muscles [2,3]. Notably, adropin is also present in the circulation [4-6]. It was found that the biological effects of adropin are conferred through the activation of $G$ protein-coupled receptor 19 (GPR19) [7-9]. More than a decade after the identification of adropin, there is convincing evidence demonstrating numerous beneficial effects of this peptide hormone on metabolic diseases such as obesity and diabetes. For instance, it was found that the overproduction or administration of adropin enhances insulin sensitivity, attenuates hepatic steatosis and delays the development of obesity in mice fed a diet 
enriched in fat [1]. Consistently, adropin deficiency in mice leads to impaired insulin sensitivity, abnormal glucose metabolism and increased adiposity [10]. Furthermore, it was found that adropin may modulate glucose homeostasis by suppressing hepatic glucose production in obese mice $[11,12]$ and by promoting glucose oxidation in skeletal muscle [13]. In addition, several studies showed an inverse correlation between plasma adropin level and body mass index (BMI) [6,14-16]. The ability of adropin to protect from increased adiposity in animals fed a high-fat diet and its negative correlation with BMI suggest that adropin may modulate the formation and possibly the functions of adipose tissue. Indeed, recently we reported that adropin promotes the proliferation of rodent white preadipocytes while suppressing their differentiation into mature adipocytes [17]. However, the direct effects of adropin on mature fat cell functions, such as glucose and lipid metabolism, as well as endocrine activity, are largely unknown. Therefore, this study aimed to investigate the effects of adropin on lipolysis, lipogenesis and glucose uptake in white adipocytes. Furthermore, we studied whether adropin is able to modulate the mRNA expression of adiponectin, resistin and visfatin.

\section{Materials and Methods}

\subsection{Materials}

Adropin ${ }^{34-76}$ was synthesized by Novazym (Poznań, Poland). Cell culture media were purchased from Corning B.V. Life Sciences (Amsterdam, The Netherlands). Antibiotics and serum were from Biowest (Nuaillé, France). Total (\#PA5-17196), and phospho-HSL (Ser563) (\#PA5-104600) antibodies were from Thermo Fisher Scientific (Waltham, MA, USA). Unless otherwise specified, all other reagents were from Sigma-Aldrich (Darmstadt, Germany).

\subsection{Cell Cultures}

Rat primary white preadipocytes were cultured in DMEM/F12 medium supplemented with $10 \%$ FBS and a mixture of penicillin $(100 \mathrm{kU} / \mathrm{L})$ and streptomycin $(100 \mathrm{mg} / \mathrm{L})$. 3T3-L1 cells (a cell model to study adipogenesis and white adipocytes functions [18]) were grown in DMEM containing the same supplements as above. Both cell cultures were maintained in optimal growth conditions (a humidified atmosphere of $5 \% \mathrm{CO}_{2}$ in air, $37^{\circ} \mathrm{C}$ ).

\subsection{Isolation of Rat Preadipocytes}

Rat primary white preadipocytes were isolated from epididymal adipose tissue depots of male Wistar rats (body weight 80-100 g, age 5-6 weeks). The fat pads were collected and pooled in a tube prefilled with sterile, freshly prepared Krebs-Ringer solution (KRB) $\left(\mathrm{NaCl} 118 \mathrm{mM}, \mathrm{KCl} 4.8 \mathrm{mM}, \mathrm{CaCl}_{2} 1.3 \mathrm{mM}, \mathrm{KH}_{2} \mathrm{PO}_{4} 1.2 \mathrm{mM}, \mathrm{MgSO}_{4} 1.2 \mathrm{mM}, \mathrm{NaHCO}_{3}\right.$ $24.8 \mathrm{mM}$, 4-(2-hydroxyethyl)-1-pipera-zineethanesulfonic acid $10 \mathrm{mM}$ ) supplemented with $5 \mathrm{mM}$ glucose, $3 \%$ BSA and antibiotics (100 kU/L penicillin and $100 \mathrm{mg} / \mathrm{L}$ streptomycin). Next, blood vessels were precisely removed, and the tissue was washed with Krebs-Ringer solution at sterile conditions. Subsequently, adipose tissue pads were mechanically minced by scissors and weighed to calculate the amount of collagenase type II needed for digestion. The tissue was digested for $60 \mathrm{~min}$ in a water bath at $37^{\circ} \mathrm{C}$ and manually shaken every $15 \mathrm{~min}$. Following the collagenase digestion, cells were centrifuged for $10 \mathrm{~min}$ at $450 \times \mathrm{g}$ at room temperature (RT). The fat and infranatant were discarded, and the pellet was resuspended in Red Blood Cell Lysing Buffer (Sigma-Aldrich) to lyse the erythrocytes. A $100 \mu \mathrm{m}$ nylon mesh was used to filter the cell suspension, and after $10 \mathrm{~min}$, the cell suspension was filtered again using $45 \mu \mathrm{m}$ mesh. Next, Krebs-Ringer solution was added $(5 \mathrm{~mL})$, and the cells were centrifuged (10 $\mathrm{min}$ at $450 \times g$ at RT). Afterwards, the supernatant was discarded, and growth medium (DMEM/F12 with 10\% FBS and antibiotics) was added to the pellet. Then, cells were counted, and the addition of $0.4 \%$ trypan blue allowed their viability to be assessed. Next, cells were seeded in 6- and 24-well plates (depending on the subsequent specific experiments) and maintained in a humidified incubator $\left(37^{\circ} \mathrm{C}\right.$, $5 \% \mathrm{CO}_{2}$ in air). The differentiation process of rat primary preadipocytes was initiated after $24 \mathrm{~h}$ of incubation (see below). 


\subsection{Preadipocyte Differentiation}

To conduct the study, preadipocytes were differentiated into mature adipocytes. The differentiation was initiated on the next day after seeding the primary preadipocytes or two days after reaching a 100\% confluency of 3T3-L1 cells. According to various research methods, cells were differentiated on 6-well plates (to analyze gene expression and protein production) or on 24-well plates (to assess lipolysis and lipogenesis). The differentiation medium for primary preadipocytes consisted of DMEM/F12, antibiotics (100 kU/L penicillin and $100 \mathrm{mg} / \mathrm{L}$ streptomycin), $850 \mathrm{nmol} / \mathrm{L}$ insulin, $2 \mathrm{nmol} / \mathrm{L} \mathrm{T} 3$ and $10 \mathrm{nmol} / \mathrm{L}$ dexamethasone. The medium was replaced with fresh differentiation medium every two days until achieving the maturation process. The differentiation of 3T3-L1 cells was induced by the incubation of cells in the growth medium (DMEM, 10\% FBS and antibiotics as described above) supplemented with $1 \mu \mathrm{mol} / \mathrm{L}$ dexamethasone, $500 \mu \mathrm{mol} / \mathrm{L} 3$-isobutyl1-methylxanthine $\backslash$ and $1 \mu \mathrm{mol} / \mathrm{L}$ insulin. On the third day of differentiation, medium was removed, cells were washed with PBS and incubated for two days in fresh growth medium supplemented with $1 \mu \mathrm{mol} / \mathrm{L}$ insulin. Afterwards, the medium was replaced with a growth medium for an additional two days. After completing the differentiation process, both cell types were incubated in the presence or absence of adropin $(0,10,100 \mathrm{nmol} / \mathrm{L})$ for different periods of time (see below) and collected for further analyses. All experiments were performed in a serum-deprived medium containing $0.1 \%$ fatty acid-free BSA $7-8$ days after the onset of the differentiation process.

\subsection{Lipolysis}

Differentiated adipocytes were incubated with or without adropin $(1,10$ or $100 \mathrm{nmol} / \mathrm{L})$ for 3 or $24 \mathrm{~h}$ in DMEM/F12 medium. Then, the medium was collected and centrifuged $(300 \times g)$ for $10 \mathrm{~min}$. Thereafter, supernatants were collected and stored at $-20^{\circ} \mathrm{C}$. Cells were scraped and lysed in RIPA buffer (Sigma-Aldrich) for $10 \mathrm{~min}$ on ice. Lysates were centrifuged $(14,000 \times g)$ for $10 \mathrm{~min}$. Supernatants were collected and stored at $-80^{\circ} \mathrm{C}$.

Glycerol was determined using Free Glycerol Reagent (Sigma-Aldrich). Free fatty acids (FFA) were measured using a NEFA HR (2) Kit (Fujifilm, Tokyo, Japan). Secreted glycerol and FFA were normalized to the total protein level, which was measured by a Pierce BCA Protein Assay Kit (Thermo Fisher Scientific).

\subsection{Lipogenesis}

Lipogenesis was measured by evaluation of D-[14C(U)] glucose (Perkin Elmer, Waltham, MA, USA) incorporation into lipids [19]. In brief, rat preadipocytes seeded and differentiated in 24-well plates were treated with or without adropin (10 or $100 \mathrm{nmol} / \mathrm{L})$ for $3 \mathrm{~h}$ in DMEM/F12 medium supplemented with $2 \%$ fatty acid-free BSA in the presence of $\mathrm{D}-[14 \mathrm{C}(\mathrm{U})]$ glucose. Then, the medium was removed, and cells were lysed using $0.1 \%$ SDS The lipid fraction was separated from the cells using Dole's extraction method [20]. Lipid phase was transferred into the scintillation liquid, and $\beta$-radiation was measured using a Liquid Scintillation Analyzer Tri-Carb 4810 TR (Perkin Elmer).

\subsection{Glucose Uptake}

Rat preadipocytes were seeded and differentiated in 24-well plates. Next, cells were incubated in a glucose-free KRB buffer containing $0.1 \%$ BSA for $30 \mathrm{~min}$. After the incubation, cells were washed with PBS and incubated for $30 \mathrm{~min}$ in KRB buffer in the presence or absence of adropin (10 or $100 \mathrm{nmol} / \mathrm{L}$ ). Next, $18.5 \mathrm{kBq}$ of deoxy-D-glucose, 2-[1-14C] glucose (Perkin Elmer) and $0.1 \mathrm{mmol} / \mathrm{L}$ 2-deoxyglucose were added, and cells were incubated for $6 \mathrm{~min}$. Then, ice-cold PBS containing $20 \mu \mathrm{mol} / \mathrm{L}$ of cytochalasin B was added. Then, KRB was aspirated, and cells were washed ( 3 times) with PBS. The cells were lysed using $0.1 \%$ SDS. Lysates were transferred into scintillation liquid and $\beta$-radiation was measured using a Liquid Scintillation Analyzer Tri-Carb 4810 TR (Perkin Elmer). 


\subsection{Real-Time PCR}

Total RNA was extracted using Extrazol reagent (Blirt, DNA Gdańsk, Poland). cDNA was synthetized using FIREScript RT cDNA Synthesis MIX with Oligo (dT) and Random primers (Solis BioDyne, Tartu, Estonia). cDNA was amplified using EvaGreen qPCR Mix (Solis BioDyne) on QuantStudio 12K Flex (Life Technologies, CA, USA). The sequences of PCR primers are shown in Table 1. Relative mRNA expression levels were calculated using the double delta CT method. The expression of mRNA of tested genes was normalized vs. Gapdh.

Table 1. Primer sequences for real-time PCR.

\begin{tabular}{|c|c|c|c|}
\hline Gene & Left Primer $\left(5^{\prime>} 3^{\prime}\right)$ & Right Primer $\left(5^{\prime>} 3^{\prime}\right)$ & $\begin{array}{l}\text { NCBI } \\
\text { Reference Sequence }\end{array}$ \\
\hline Adiponectin (rat) & tggtcacaatgggataccg & cccttaggaccaagaacacct & NM_144744.3 \\
\hline Gapdh (rat) & ctgcaccaccaactgcttag & tgatggcatggactgtgg & NM_017008.4 \\
\hline Hsl (rat) & cccaaagtaagaggcacagagt & tcctggcattcctggtctttc & NM_012859.1 \\
\hline Resistin (rat) & gccgctgtccagtctat & cattgctggtcagtctcc & NM_144741.1 \\
\hline Visfatin (rat) & cacaagagactgccggcatag & tttcccccacgctgttatgg & NM_177928.3 \\
\hline Adiponectin (mouse) & atctggaggtgggagaccaa & gggctatgggtagttgcagt & NM_009605.5 \\
\hline Gapdh (mouse) & atggtgaaggtcggtgtga & aatctccactttgccactgc & NM_001289726.1 \\
\hline Resistin (mouse) & tgaagatggatggcgaagtgg & gtggtgtaaatgccetgggt & NM_022984.4 \\
\hline Visfatin (mouse) & ccataacggcttgggggaaa & gctatcgctgaccacagaca & NM_021524.2 \\
\hline
\end{tabular}

\subsection{Western Blot}

The Western blot technique was used to detect phosphorylated and total HSL. Cells were differentiated and then incubated with adropin $(100 \mathrm{nmol} / \mathrm{L})$ for the indicated time points (0-60 min). Next, cell plates were placed on ice and washed with ice-cold PBS. RIPA buffer (Sigma-Aldrich), with an addition of protease and phosphatase inhibitor cocktails (Roche Diagnostics, Mannheim, Germany), was used to lyse cells and to isolate proteins. Tubes with collected cells, after incubation on ice $(10 \mathrm{~min})$, were centrifuged $(14.000 \times \mathrm{g}$ at $4{ }^{\circ} \mathrm{C}$ for $10 \mathrm{~min}$ ), and then the supernatants were collected. Furthermore, we determined protein concentration by a BCA Protein Assay Kit (Thermo Fisher Scientific). Every sample containing $30 \mu \mathrm{g}$ of protein was diluted in a loading buffer and then denatured $\left(95^{\circ} \mathrm{C}\right.$, $5 \mathrm{~min}$ ). SDS-PAGE (5-12\% Tris- $\mathrm{HCl}$ gel) was applied to separate proteins based on their molecular weight. Afterwards, proteins were transferred onto polyvinylidene difluoride (PVDF) membranes, which were blocked for $1 \mathrm{~h}$ at RT in 5\% BSA in TBST $(50 \mathrm{mmol} / \mathrm{L}$ Tris, $100 \mathrm{mmol} / \mathrm{L} \mathrm{NaCl}, 0.1 \%$ Tween 20, $\mathrm{pH} 7.4$ ). We incubated the membranes with a primary antibody (phosphorylated HSL, overnight, $4{ }^{\circ} \mathrm{C}$ ) and washed them three times (for 10 min each) with TBST. Next, the membranes were incubated with a secondary antibody for $1.5 \mathrm{~h}$ at RT and washed again (as described above). Following the last wash, the signal was detected using chemiluminescence (Immobilon Forte Western HRP substrate, Merck Millipore, MA, USA) and visualized by ChemiDoc MP Imaging System (Bio-Rad Laboratories, Hercules, CA, USA). Then, the membranes were stripped and the process was repeated for the total HSL antibody. The dilution was 1:1000 for primary antibodies and 1:5000 for secondary antibodies.

\subsection{Statistical Analysis}

Data were compared using one-way ANOVA followed by the Bonferroni post hoc. $p<0.05\left(^{*}\right)$ was considered to be statistically significant. All experiments were repeated at least two times. 


\section{Results}

\subsection{Adropin Promotes Lipolysis in Rat Primary Adipocytes}

First, we evaluated the effects of adropin on lipolysis in differentiated rat primary preadipocytes. The successful differentiation of both white fat precursor cells is shown in Figure 1. It is noteworthy that undifferentiated rat white primary preadipocytes (Figure 1a) and 3T3-L1 cells (Figure 1c) display fibroblast-like morphologies and an absence of lipid droplets. By contrast, rat adipocytes (Figure 1b) and 3T3-L1 cells (Figure 1d) differentiated for 7 days have a characteristic spherical shape and contain lipid droplets. As shown in Figure $2 \mathrm{a}, \mathrm{c}$, adropin $(100 \mathrm{nmol} / \mathrm{L})$ increased glycerol and FFA release in rat adipocytes incubated for $3 \mathrm{~h}$. By contrast, adropin failed to modulate glycerol and FFA release in rat adipocytes exposed to adropin for $24 \mathrm{~h}$ (Figure $2 \mathrm{~b}, \mathrm{~d}$ ). Furthermore, the release of glycerol (Figure 2e-f) and FFA (Figure 2g-h) increased in differentiated 3T3-L1 cells incubated with adropin (10 and/or $100 \mathrm{nmol} / \mathrm{L}$ ) for 3 and $24 \mathrm{~h}$. These results show that adropin stimulates lipolysis in rat primary adipocytes and 3T3-L1 cells. Nevertheless, the observed changes were moderate.

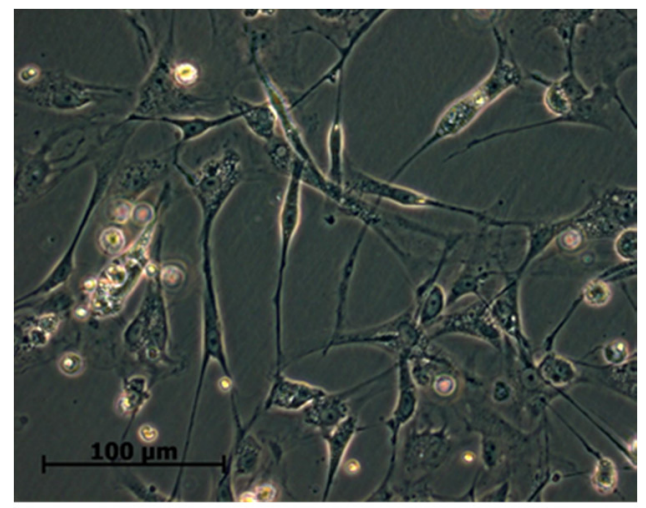

(a)

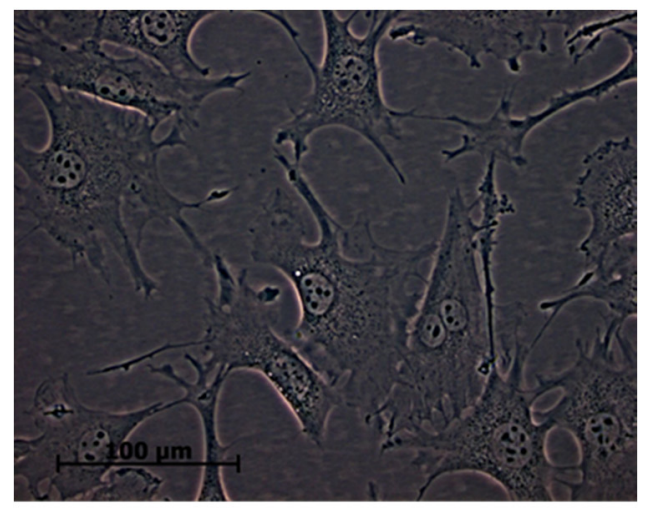

(c)

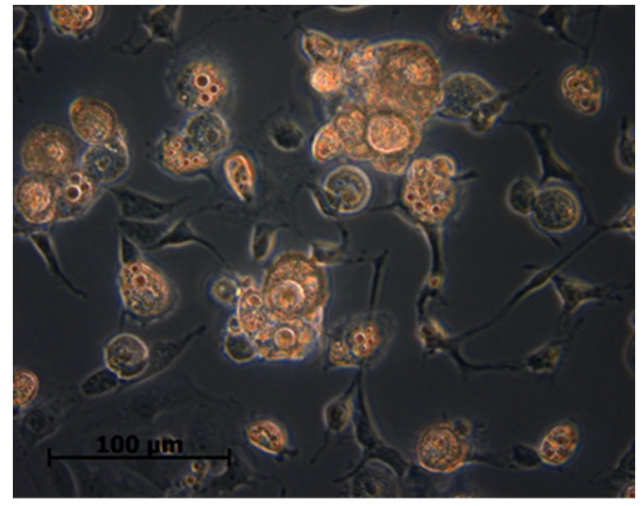

(b)

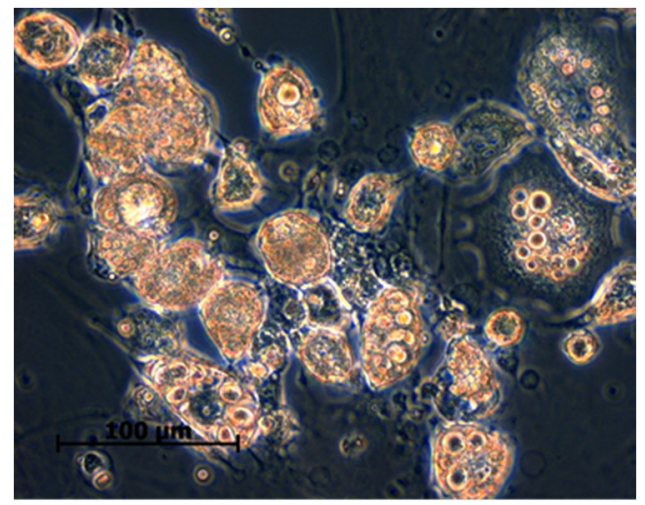

(d)

Figure 1. Images of rat adipocytes and 3T3-L1 cells. Undifferentiated rat preadipocytes (a) and adipocytes differentiated for 7 days (b). Undifferentiated 3T3-L1 (c) and 3T3-L1 cells differentiated for 7 days (d).

Next, we studied the effects of adropin on the mRNA expression and phosphorylation of hormone-sensitive lipase (HSL) in rat adipocytes. As shown in Figure 3a, adropin had no effect on $\mathrm{Hsl} \mathrm{mRNA}$ expression assessed in rat adipocytes treated with adropin (10 and $100 \mathrm{nmol} / \mathrm{L})$ for $3 \mathrm{~h}$. However, adropin $(100 \mathrm{nmol} / \mathrm{L})$ promoted HSL phosphorylation in these cells (Figure $3 b, c$ ). 


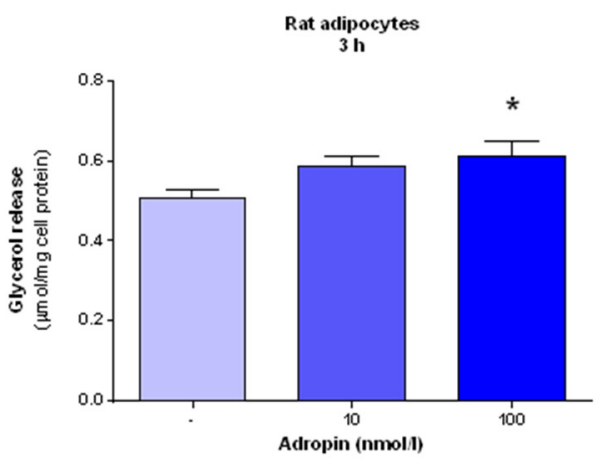

(a)

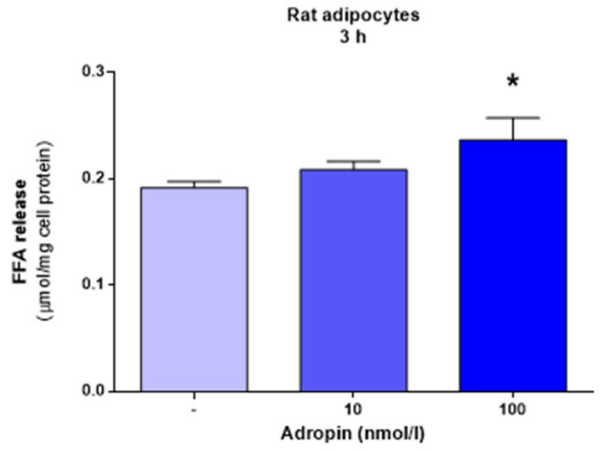

(c)

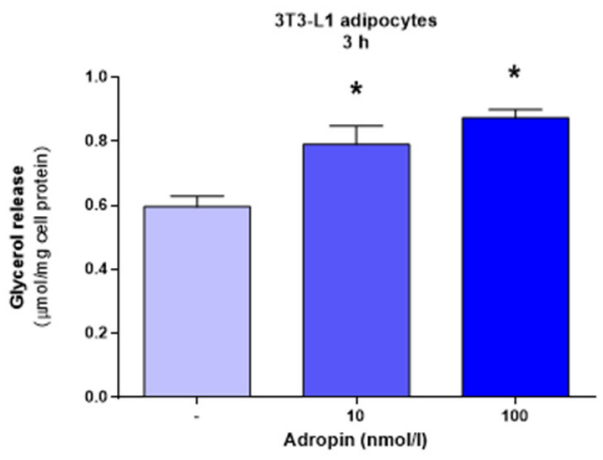

(e)

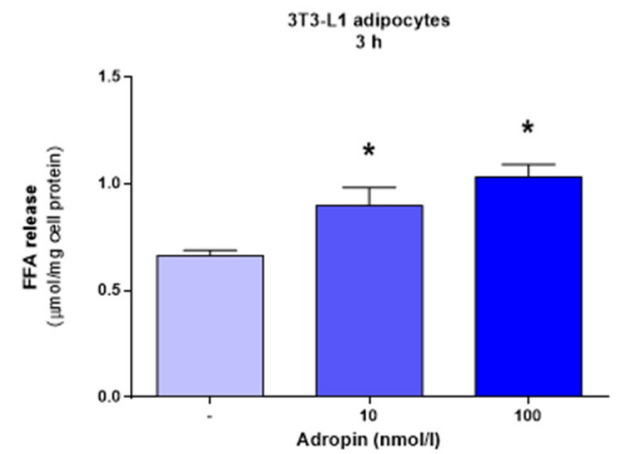

(g)

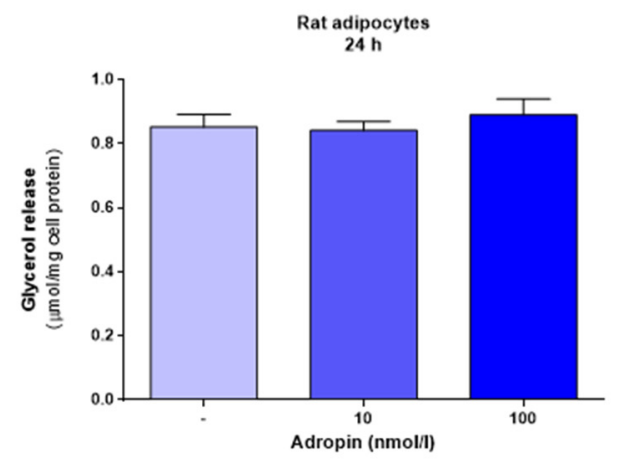

(b)

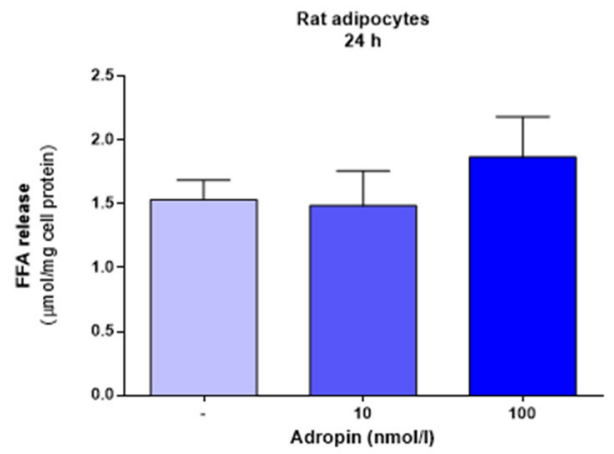

(d)

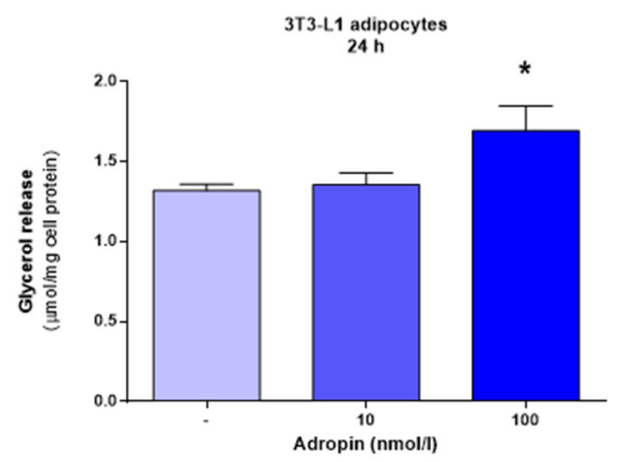

(f)

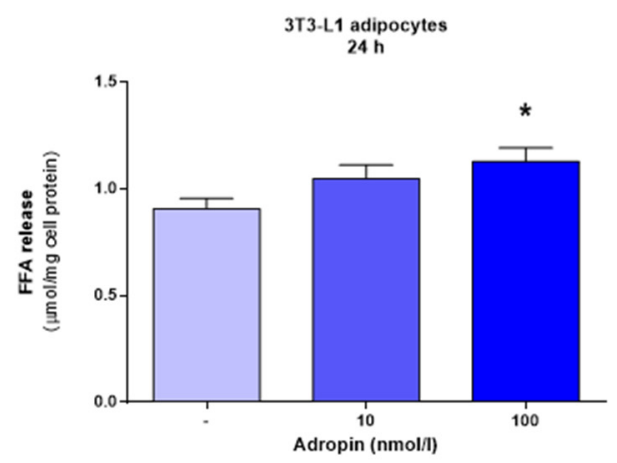

(h)

Figure 2. The effects of adropin (10 or $100 \mathrm{nmol} / \mathrm{L}$ ) or vehicle (sterile distilled water) (-) on lipolysis in rat primary adipocytes and 3T3-L1 adipocytes. The effects of adropin (10 or $100 \mathrm{nmol} / \mathrm{L})$ on glycerol release in rat adipocytes assessed after 3 (a) or $24 \mathrm{~h} \mathrm{(b)}$ of incubation. FFA release determined in rat adipocytes exposed to adropin for 3 (c) and $24 \mathrm{~h}$ (d). The effects of adropin on glycerol release in 3T3-L1 cells treated with adropin for 3 (e) or $24 \mathrm{~h}$ (f). Secretion of FFA from 3T3-L1 incubated in the presence of adropin for $3(\mathrm{~g})$ or $24 \mathrm{~h}(\mathbf{h})$. Results are the mean $\pm \operatorname{SEM}(\mathrm{n}=5-6) . p<0.05\left(^{*}\right)$. 


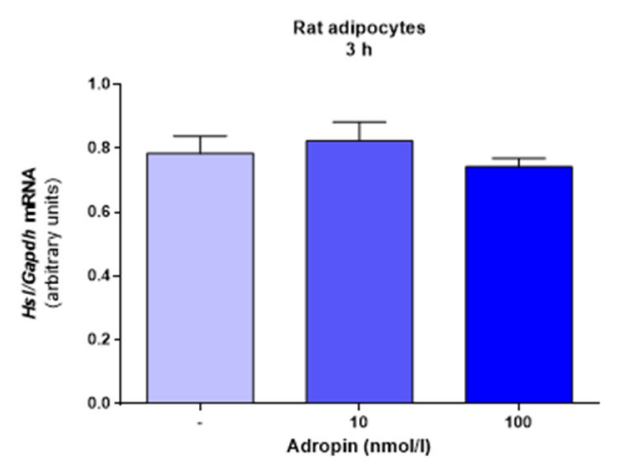

(a)

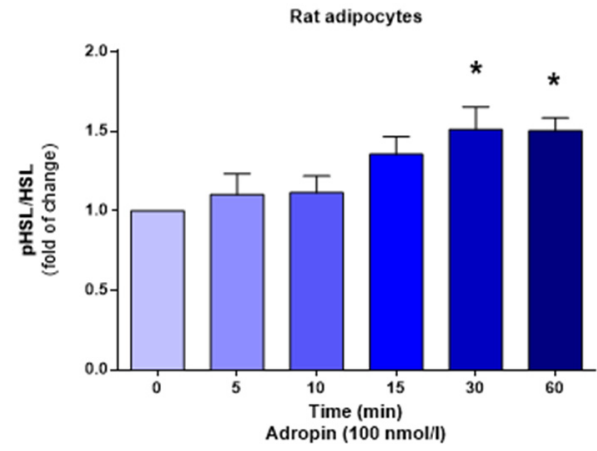

(c)

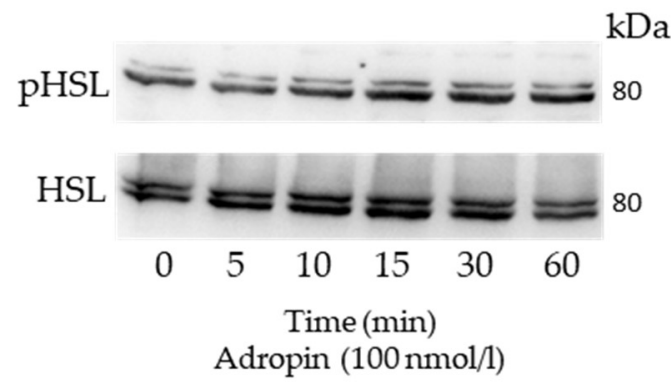

(b)

Figure 3. The effects of adropin on Hsl mRNA expression and HSL phosphorylation in rat adipocytes. Hsl mRNA determined in cells exposed to adropin for $3 \mathrm{~h}$ or vehicle (sterile distilled water) (-) (a). Phosphorylation of HSL in cells treated with adropin $(100 \mathrm{nmol} / \mathrm{L})$ for the indicated time points $(\mathbf{b}, \mathbf{c})$. Note the presence of two bands $(84$ and $89 \mathrm{kDa})$ corresponding to two HSL isoforms [21]. Results are the mean \pm SEM (PCR $n=6$, Western blot $n=4)$. $p<0.05\left(^{*}\right)$.

\subsection{Adropin Inhibits Lipogenesis but Fails to Modulate Glucose Uptake in Rat Primary Preadipocytes}

As shown in Figure 4a, adropin at the concentration of 10 or $100 \mathrm{nmol} / \mathrm{L}$ slightly reduced lipogenesis in rat primary preadipocytes. By contrast, adropin $(10$ and $100 \mathrm{nmol} / \mathrm{L})$ failed to affect glucose uptake in differentiated rat adipocytes (Figure 4b).

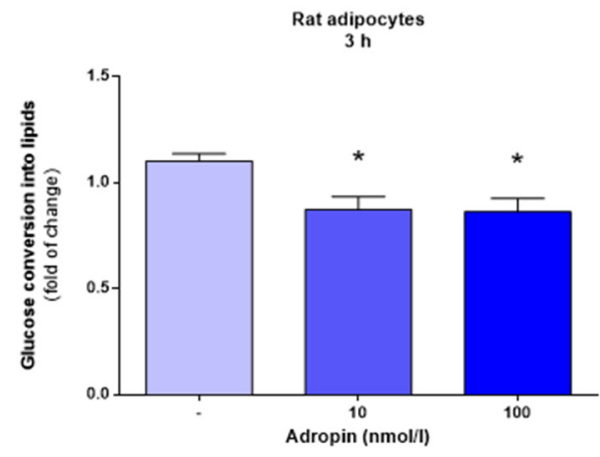

(a)

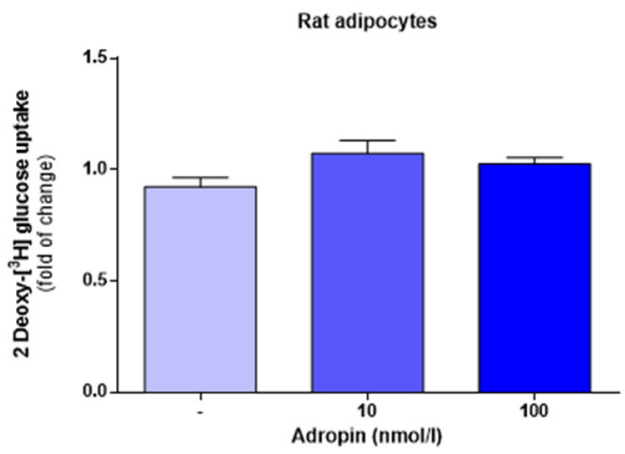

(b)

Figure 4. The effects of adropin on lipogenesis and glucose uptake in rat preadipocytes. Incorporation of (C14) glucose into lipids in cells exposed to adropin (10 or $100 \mathrm{nmol} / \mathrm{L})$ or vehicle (sterile distilled water) (-) for $3 \mathrm{~h}$ (a). Glucose uptake in adipocytes treated with adropin $(10$ or $100 \mathrm{nmol} / \mathrm{L})$ for $30 \mathrm{~min}(\mathbf{b})$. Results are the mean $\pm \operatorname{SEM}(n=8)$. $p<0.05\left(^{*}\right)$. 


\subsection{Adropin Modulates Adipokine mRNA Expression}

Next, we evaluated the effects of adropin on the mRNA expression of selected adipokines, such as adiponectin, resistin and visfatin. As demonstrated in Figure 5a,b, adropin (10 and $100 \mathrm{nmol} / \mathrm{L}$ ) promoted adiponectin mRNA expression in rat preadipocytes assessed after $3 \mathrm{~h}$, but not after $24 \mathrm{~h}$. By contrast, adropin (10 and $100 \mathrm{nmol} / \mathrm{L})$ suppressed the mRNA expression of resistin (Figure $5 c, d$ ) and visfatin (Figure 5 e,f) in rat adipocytes determined after 3 or $24 \mathrm{~h}$ of incubation. Furthermore, an increased expression of adiponectin mRNA was detected in 3T3-L1 exposed to adropin (10 and $100 \mathrm{nmol} / \mathrm{L})$ for 3 or $24 \mathrm{~h}$ (Figure 5g,h). In 3T3-L1 cells, adropin (100 nmol/L) downregulated resistin (Figure 5i,j) and visfatin (Figure 5k,l) mRNA expression after $24 \mathrm{~h}$, but not after $3 \mathrm{~h}$. These results show that adropin promotes adiponectin expression but suppresses the expression of resistin and visfatin in rat adipocytes and 3T3-L1 cells.

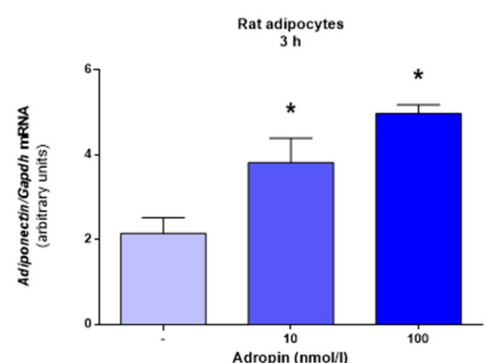

(a)

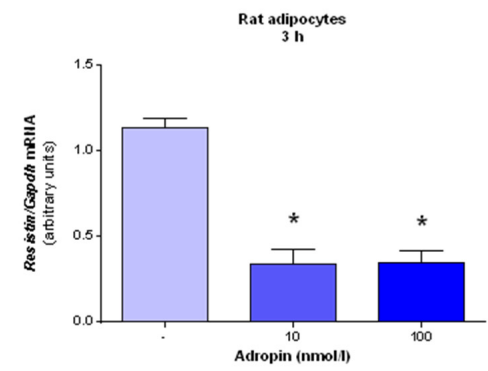

(c)

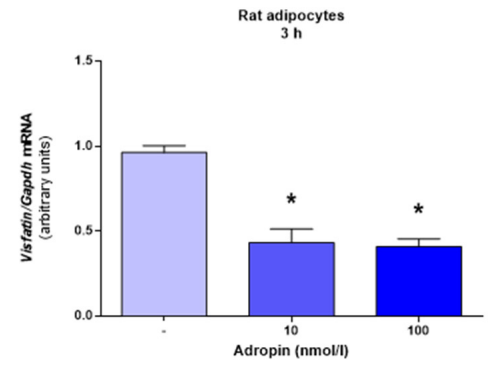

(e)

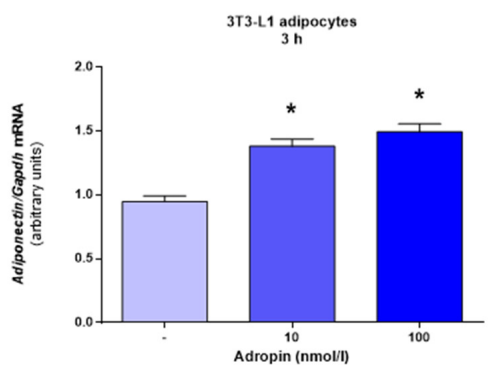

(g)

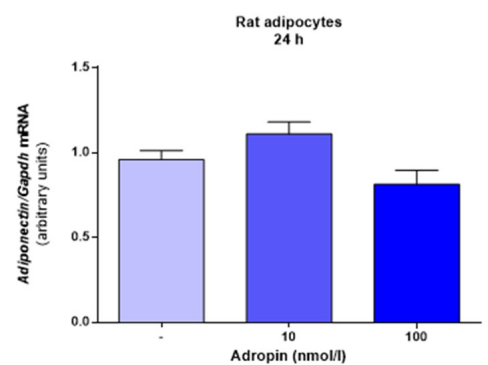

(b)

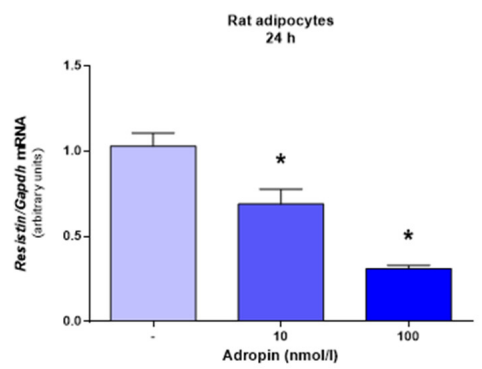

(d)

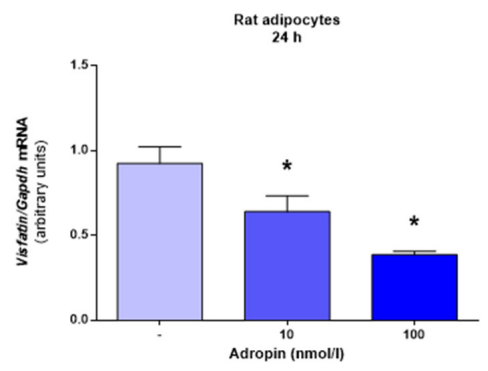

(f)

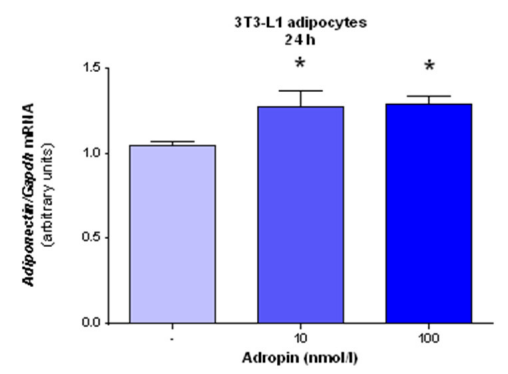

(h)

Figure 5. Cont. 


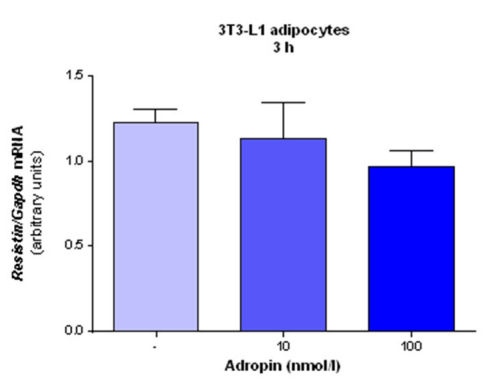

(i)

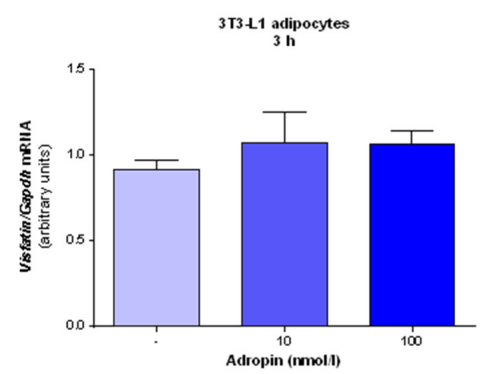

(k)

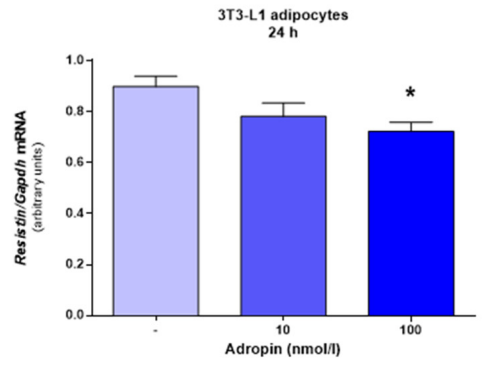

(j)

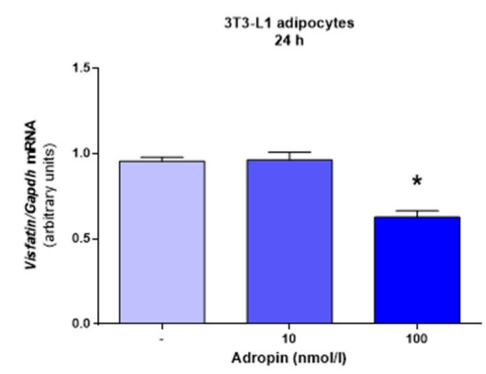

(1)

Figure 5. Effects of adropin on mRNA expression of adiponectin, resistin and visfatin in rat adipocytes and 3T3-L1 cells. Expression of adiponectin mRNA in rat adipocytes treated with adropin or vehicle (sterile distilled water) (-) for 3 (a) or $24 \mathrm{~h} \mathrm{(b)}$. Expression of resistin mRNA in rat adipocytes treated with adropin for $3(\mathbf{c})$ or $24 \mathrm{~h}(\mathrm{~d})$. The mRNA levels of visfatin assessed in rat adipocytes incubated in the presence of adropin for 3 (e) or $24 \mathrm{~h}$ (f). Expression of adiponectin mRNA in 3T3-L1 cells treated with adropin for $3(\mathbf{g})$ or $24 \mathrm{~h}(\mathbf{h})$. Resistin mRNA expression in 3T3-L1 cells treated with adropin for 3 (i) or $24 \mathrm{~h}(\mathbf{j})$. Visfatin mRNA levels in 3T3-L1 cells determined in cells exposed to adropin for $3(\mathbf{k})$ or $24 \mathrm{~h}(\mathbf{l})$. Results are the mean $\pm \operatorname{SEM}(n=6) . p<0.05\left(^{*}\right)$.

\section{Discussion}

In this study, we report that adropin modulates lipid metabolism and the mRNA expression of adiponectin, resistin and visfatin in mature white fat rodent cells. Firstly, we found that acting on differentiated rat adipocytes and 3T3-L1 cells, adropin slightly promotes the secretion of glycerol and FFA, the hallmarks of lipolysis [22]. In our previous study, we found that adropin is able to downregulate the differentiation of white and brown rodent preadipocytes into mature fat cells $[17,23]$. Importantly, the suppressive effect on the differentiation of both types of preadipocytes was accompanied by lower intracellular lipid content, suggesting that adropin may be involved in controlling lipid metabolism. Consistently, other studies reported that adropin is able to reduce lipogenic gene mRNA expression, such as Ppar $\gamma, S c d 1$ and Fas in white adipose tissue [1]. Therefore, these results suggest that adropin may affect intracellular lipid content by the suppression of lipid accumulation during adipogenic differentiation and by promoting the lipolytic activity of white mature adipocytes.

The regulation of lipolysis in white adipocytes is complex, and it is modulated by numerous metabolic, hormonal and environmental signals [24]. Nevertheless, there is convincing evidence that fat mobilization is strongly modulated by HSL [24,25]. Therefore, since we observed that adropin moderately promotes lipolysis in adipocytes, we assessed the effect of this peptide on the mRNA expression and phosphorylation of HSL. Our data indicate that adropin failed to affect $\mathrm{Hsl}$ mRNA levels but enhanced the phosphorylation of HSL at serine 563. It is worth noting that the phosphorylation of HSL at serine 563 is promoted by lipolysis-inducing factors $[19,26-28]$. These results provide evidence that adropin may modulate lipolysis to a slight extend by activating HSL in white adipocytes.

In addition to lipolysis, intracellular fat content in adipocytes is modulated by other processes, such as lipid synthesis termed as lipogenesis [29]. Therefore, to study the role of adropin in lipid metabolism in more detailed fashion, we evaluated the effects of adropin on 
glucose incorporation into lipids as a surrogate marker of lipogenesis [30]. Here, we found that by acting on white rat adipocytes, adropin slightly decreased the conversion of glucose into FFA. Thus, these results show that adropin moderately suppresses the synthesis of lipids de novo.

In adipose tissue, lipogenesis depends upon the availability of carbohydrates in circulation, as well as their uptake by adipocytes [31]. Therefore, we studied the ability of adropin to modulate glucose uptake in differentiated rat adipocytes. Adropin had no effect on glucose transport in rat adipocytes. Overall, these results collectively demonstrate that adropin may reduce intracellular lipid storage in adipocytes by promoting lipolysis and by suppressing de novo lipid synthesis. These results were moderate; however, these in vitro findings are consistent with the results of in vivo experiments, showing that adropin protects from adiposity $[1,10]$.

Next, we evaluated the influence of adropin on the mRNA expression of selected adipokines involved in controlling energy homeostasis and metabolism, such as adiponectin, resistin and visfatin $[32,33]$. We found that adropin promoted the mRNA expression of adiponectin in rat adipocytes as well as in differentiated 3T3-L1 cells. In contrast, adropin downregulated the mRNA expression of resistin and visfatin in both types of adipocytes.

It is worth to note that adiponectin is able to improve insulin sensitivity [34], which resembles the therapeutic effects of adropin in animal models of diet-induced obesity [35]. Nevertheless, it remains to be investigated whether the beneficial effects of adropin on insulin sensitivity, reported in obese animals, are dependent upon adropin-modulated adiponectin expression.

By contrast, it was found that resistin impairs glucose tolerance and insulin action in rodents [36]. Furthermore, human and animal studies suggested that resistin contributes to inflammation [37-39]. Similarly, visfatin was found to induce inflammation and insulin resistance in hepatocytes [40]. Therefore, these two adipokines are instead considered as proinflammatory signals. Since adropin suppresses the expression of these adipokines, adropin can be considered as an anti-inflammatory factor (extensively reviewed in [41]). For instance, adropin displays anti-inflammatory properties in a liver in a rat model of hyperlipidemia [42]. A negative correlation between circulating adropin and proinflammatory signals, such as TNF $\alpha$ or IL-6, was reported in patients with obstructive sleep apnea [43]. Furthermore, a recent study showed that adropin is able to attenuate neuroinflammation in rats [44]. Thus, since inflammation leads to obesity-associated abnormalities [45], it is rational to speculate that the suppression of proinflammatory cytokine production by adropin may at least partially contribute to the attenuation of metabolic derangements reported in animal models of insulin resistance and obesity. Nevertheless, more in vivo experiments are needed to confirm this speculation.

Our study has several limitations. First of all, we did not elucidate the mechanism conferring the activation of HSL or lipolysis by adropin and its putative receptor GPR19. However, it was found that in tilapia hepatocytes, adropin promotes LPL expression via a cAMP/PKA-dependent mechanism [46], which was also implicated in the activation of HSL, and lipolysis in white adipocytes [47]. Furthermore, it remains to be investigated whether changes in the expression of adipokines are accompanied by changes in protein production and/or secretion in vitro or in vivo.

\section{Conclusions}

In summary, we found that by acting on white rodent adipocytes, adropin slightly stimulates lipolysis while suppressing de novo lipid synthesis. However, these effects were moderate. Furthermore, adropin stimulates the expression of adiponectin; however, it downregulates the expression of resistin and visfatin (Figure 6). Overall, these results show that adropin may modulate lipid metabolism and endocrine function in white adipose tissue in vitro. 


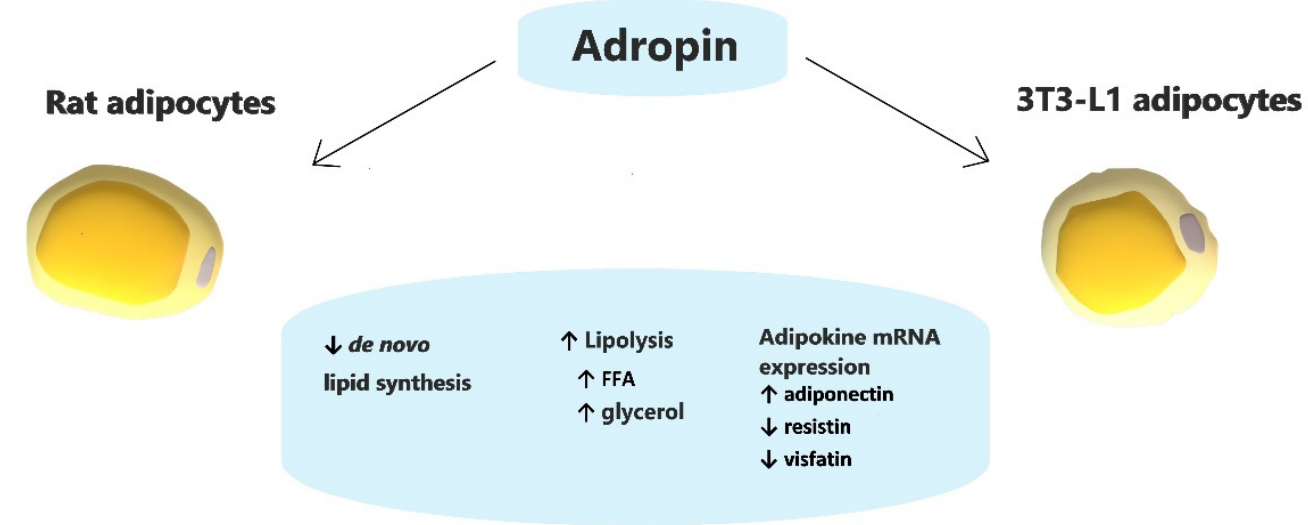

Figure 6. Schematic summary of the effects of adropin on white rodent adipocytes.

Author Contributions: Conceptualization, M.S. and M.J.; methodology, M.J. and M.S.; software, M.J.; validation, M.J. and M.S.; formal analysis, M.J. and M.S.; investigation, M.J., T.W. and E.P.-O.; resources, M.S.; data curation, M.J. and M.S.; writing-original draft preparation, M.J. and M.S.; writing-review and editing, M.Z.S.; visualization, M.J.; supervision, K.W.N.; project administration, M.S.; funding acquisition, M.S. and M.J. All authors have read and agreed to the published version of the manuscript.

Funding: This research was funded by the National Science Centre of Poland (grant number 2016/23/D/NZ4/03557 to M. Skrzypski). The research was supported by the 2020 grant of the Young Researcher Program of the Faculty of Veterinary Medicine and Animal Science, Poznan University of Life Sciences, to Mariami Jasaszwili, financed by the Polish Ministry of Science and Higher Education.

Institutional Review Board Statement: All animal procedures were carried out in accordance with Polish law.

Informed Consent Statement: Not applicable.

Data Availability Statement: The data presented in this study are available on reasonable request from the corresponding author.

Conflicts of Interest: The authors declare no conflict of interest. The funders had no role in the design of the study; in the collection, analyses, or interpretation of data; in the writing of the manuscript or in the decision to publish the results.

\section{Abbreviations}

BSA: bovine serum albumin; cAMP, cyclic adenosine monophosphate; DMEM, Dulbecco's Modified Eagle's medium; Fas, fas cell surface death receptor; FBS, fetal bovine serum; Gapdh, glyceraldehyde 3-phosphate dehydrogenase; IBMX, 3-isobutyl-1-methylxanthin; IL-6, interleukin 6; LPL, lipoprotein lipase; PBS, phosphate-buffered saline; PKA, protein kinase A; Ppar $\gamma$, peroxisome proliferator-activated receptor $\gamma$; Scd1, stearoyl-CoA desaturase; SDS, sodium dodecyl sulfate; T3, triiodothyronine; TNF- $\alpha$, tumor necrosis factor $\alpha$.

\section{References}

1. Kumar, K.G.; Trevaskis, J.L.; Lam, D.D.; Sutton, G.M.; Koza, R.A.; Chouljenko, V.N.; Kousoulas, K.G.; Rogers, P.M.; Kesterson, R.A.; Thearle, M.; et al. Identification of adropin as a secreted factor linking dietary macronutrient intake with energy homeostasis and lipid metabolism. Cell Metab. 2008, 8, 468-481. [CrossRef]

2. Aydin, S.; Kuloglu, T.; Aydin, S.; Eren, M.N.; Yilmaz, M.; Kalayci, M.; Sahin, I.; Kocaman, N.; Citil, C.; Kendir, Y. Expression of adropin in rat brain, cerebellum, kidneys, heart, liver, and pancreas in streptozotocin-induced diabetes. Mol. Cell. Biochem. 2013, 380, 73-81. [CrossRef] [PubMed]

3. Butler, A.A.; Zhang, J.; Price, C.A.; Stevens, J.R.; Graham, J.L.; Stanhope, K.L.; King, S.; Krauss, R.M.; Bremer, A.A.; Havel, P.J. Low plasma adropin concentrations increase risks of weight gain and metabolic dysregulation in response to a high-sugar diet in male nonhuman primates. J. Biol. Chem. 2019, 294, 9706-9719. [CrossRef] [PubMed] 
4. Lian, W.; Gu, X.; Qin, Y.; Zheng, X. Elevated plasma levels of adropin in heart failure patients. Intern. Med. 2011, 50, 1523-1527. [CrossRef]

5. Neethu, A.; Jayashree, K.; Senthilkumar, G.P.; Ramesh Babu, K.; Vadivelan, M. Circulating adropin and vascular endothelial growth factor receptor-2 levels in age-related macular degeneration and T2DM patients-A cross-sectional study. J. Fam. Med. Prim. Care 2020, 9, 4875-4879. [CrossRef]

6. Butler, A.A.; Tam, C.S.; Stanhope, K.L.; Wolfe, B.M.; Ali, M.R.; O’Keeffe, M.; St-Onge, M.P.; Ravussin, E.; Havel, P.J. Low circulating adropin concentrations with obesity and aging correlate with risk factors for metabolic disease and increase after gastric bypass surgery in humans. J. Clin. Endocrinol. Metab. 2012, 97, 3783-3791. [CrossRef]

7. Stein, L.M.; Yosten, G.L.; Samson, W.K. Adropin acts in brain to inhibit water drinking: Potential interaction with the orphan G protein-coupled receptor, GPR19. Am. J. Physiol. Regul. Integr. Comp. Physiol. 2016, 310, R476-R480. [CrossRef]

8. Rao, A.; Herr, D.R. G protein-coupled receptor GPR19 regulates E-cadherin expression and invasion of breast cancer cells. Biochim. Biophys. Acta Mol. Cell Res. 2017, 1864, 1318-1327. [CrossRef]

9. Thapa, D.; Stoner, M.W.; Zhang, M.; Xie, B.; Manning, J.R.; Guimaraes, D.; Shiva, S.; Jurczak, M.J.; Scott, I. Adropin regulates pyruvate dehydrogenase in cardiac cells via a novel GPCR-MAPK-PDK4 signaling pathway. Redox Biol. 2018, 18, 25-32. [CrossRef]

10. Ganesh Kumar, K.; Zhang, J.; Gao, S.; Rossi, J.; McGuinness, O.P.; Halem, H.H.; Culler, M.D.; Mynatt, R.L.; Butler, A.A. Adropin deficiency is associated with increased adiposity and insulin resistance. Obesity 2012, 20, 1394-1402. [CrossRef] [PubMed]

11. Thapa, D.; Xie, B.; Manning, J.R.; Zhang, M.; Stoner, M.W.; Huckestein, B.R.; Edmunds, L.R.; Zhang, X.; Dedousis, N.L.; O'Doherty, R.M.; et al. Adropin reduces blood glucose levels in mice by limiting hepatic glucose production. Physiol. Rep. 2019, 7, e14043. [CrossRef]

12. Gao, S.; Ghoshal, S.; Zhang, L.; Stevens, J.R.; McCommis, K.S.; Finck, B.N.; Lopaschuk, G.D.; Butler, A.A. The peptide hormone adropin regulates signal transduction pathways controlling hepatic glucose metabolism in a mouse model of diet-induced obesity. J. Biol. Chem. 2019, 294, 13366-13377. [CrossRef]

13. Gao, S.; McMillan, R.P.; Jacas, J.; Zhu, Q.; Li, X.; Kumar, G.K.; Casals, N.; Hegardt, F.G.; Robbins, P.D.; Lopaschuk, G.D.; et al. Regulation of substrate oxidation preferences in muscle by the peptide hormone adropin. Diabetes 2014, 63, 3242-3252. [CrossRef]

14. Sayin, O.; Tokgoz, Y.; Arslan, N. Investigation of adropin and leptin levels in pediatric obesity-related nonalcoholic fatty liver disease. J. Pediatric Endocrinol. Metab. JPEM 2014, 27, 479-484. [CrossRef]

15. Yu, H.Y.; Zhao, P.; Wu, M.C.; Liu, J.; Yin, W. Serum adropin levels are decreased in patients with acute myocardial infarction. Regul. Pept. 2014, 190-191, 46-49. [CrossRef]

16. Zang, H.; Jiang, F.; Cheng, X.; Xu, H.; Hu, X. Serum adropin levels are decreased in Chinese type 2 diabetic patients and negatively correlated with body mass index. Endocr. J. 2018, 65, 685-691. [CrossRef]

17. Jasaszwili, M.; Wojciechowicz, T.; Billert, M.; Strowski, M.Z.; Nowak, K.W.; Skrzypski, M. Effects of adropin on proliferation and differentiation of 3T3-L1 cells and rat primary preadipocytes. Mol. Cell. Endocrinol. 2019, 496, 110532. [CrossRef] [PubMed]

18. Ruiz-Ojeda, F.J.; Ruperez, A.I.; Gomez-Llorente, C.; Gil, A.; Aguilera, C.M. Cell Models and Their Application for Studying Adipogenic Differentiation in Relation to Obesity: A Review. Int. J. Mol. Sci. 2016, 17, 1040. [CrossRef] [PubMed]

19. Kolodziejski, P.A.; Pruszynska-Oszmalek, E.; Micker, M.; Skrzypski, M.; Wojciechowicz, T.; Szwarckopf, P.; Skieresz-Szewczyk, K.; Nowak, K.W.; Strowski, M.Z. Spexin: A novel regulator of adipogenesis and fat tissue metabolism. Biochim. Biophys. Acta Mol. Cell Biol. Lipids 2018, 1863, 1228-1236. [CrossRef]

20. Dole, V.P.; Meinertz, H. Microdetermination of long-chain fatty acids in plasma and tissues. J. Biol. Chem. 1960, 235, 2595-2599. [CrossRef]

21. Lindvall, H.; Nevsten, P.; Strom, K.; Wallenberg, R.; Sundler, F.; Langin, D.; Winzell, M.S.; Holm, C. A novel hormone-sensitive lipase isoform expressed in pancreatic $\beta$-cells. J. Biol. Chem. 2004, 279, 3828-3836. [CrossRef]

22. Langin, D. Control of fatty acid and glycerol release in adipose tissue lipolysis. Comptes Rendus Biol. 2006, 329, 598-607. [CrossRef]

23. Jasaszwili, M.; Wojciechowicz, T.; Strowski, M.Z.; Nowak, K.W.; Skrzypski, M. Adropin stimulates proliferation but suppresses differentiation in rat primary brown preadipocytes. Arch. Biochem. Biophys. 2020, 692, 108536. [CrossRef]

24. Duncan, R.E.; Ahmadian, M.; Jaworski, K.; Sarkadi-Nagy, E.; Sul, H.S. Regulation of lipolysis in adipocytes. Annu. Rev. Nutr. 2007, 27, 79-101. [CrossRef] [PubMed]

25. Nielsen, T.S.; Jessen, N.; Jorgensen, J.O.; Moller, N.; Lund, S. Dissecting adipose tissue lipolysis: Molecular regulation and implications for metabolic disease. J. Mol. Endocrinol. 2014, 52, R199-R222. [CrossRef]

26. Djouder, N.; Tuerk, R.D.; Suter, M.; Salvioni, P.; Thali, R.F.; Scholz, R.; Vaahtomeri, K.; Auchli, Y.; Rechsteiner, H.; Brunisholz, R.A.; et al. PKA phosphorylates and inactivates AMPKalpha to promote efficient lipolysis. EMBO J. 2010, 29, 469-481. [CrossRef]

27. Martin, S.; Okano, S.; Kistler, C.; Fernandez-Rojo, M.A.; Hill, M.M.; Parton, R.G. Spatiotemporal regulation of early lipolytic signaling in adipocytes. J. Biol. Chem. 2009, 284, 32097-32107. [CrossRef]

28. Ge, M.; Guo, R.; Lou, H.X.; Zhang, W. Extract of Paecilomyces hepiali mycelia induces lipolysis through PKA-mediated phosphorylation of hormone-sensitive lipase and ERK-mediated downregulation of perilipin in 3T3-L1 adipocytes. BMC Complement. Altern. Med. 2018, 18, 326. [CrossRef] [PubMed]

29. Kersten, S. Mechanisms of nutritional and hormonal regulation of lipogenesis. EMBO Rep. 2001, 2, 282-286. [CrossRef]

30. Takano, T.; Hennes, A.R.; Power, L. Insulin-stimulated lipogenesis in rat adipose tissue in vitro: Incorporation of C14 from glucose and acetate into lipid fractions and fatty acids. Metabolism 1967, 16, 933-940. [CrossRef] 
31. Song, Z.; Xiaoli, A.M.; Yang, F. Regulation and Metabolic Significance of De Novo Lipogenesis in Adipose Tissues. Nutrients 2018, 10, 1383. [CrossRef]

32. Fasshauer, M.; Bluher, M. Adipokines in health and disease. Trends Pharmacol. Sci. 2015, 36, 461-470. [CrossRef]

33. Tripathi, D.; Kant, S.; Pandey, S.; Ehtesham, N.Z. Resistin in metabolism, inflammation, and disease. FEBS J. 2020, 287, 3141-3149. [CrossRef]

34. Kadowaki, T.; Yamauchi, T.; Kubota, N.; Hara, K.; Ueki, K.; Tobe, K. Adiponectin and adiponectin receptors in insulin resistance, diabetes, and the metabolic syndrome. J. Clin. Investig. 2006, 116, 1784-1792. [CrossRef] [PubMed]

35. Gao, S.; McMillan, R.P.; Zhu, Q.; Lopaschuk, G.D.; Hulver, M.W.; Butler, A.A. Therapeutic effects of adropin on glucose tolerance and substrate utilization in diet-induced obese mice with insulin resistance. Mol. Metab. 2015, 4, 310-324. [CrossRef] [PubMed]

36. Steppan, C.M.; Bailey, S.T.; Bhat, S.; Brown, E.J.; Banerjee, R.R.; Wright, C.M.; Patel, H.R.; Ahima, R.S.; Lazar, M.A. The hormone resistin links obesity to diabetes. Nature 2001, 409, 307-312. [CrossRef] [PubMed]

37. Patel, L.; Buckels, A.C.; Kinghorn, I.J.; Murdock, P.R.; Holbrook, J.D.; Plumpton, C.; Macphee, C.H.; Smith, S.A. Resistin is expressed in human macrophages and directly regulated by PPAR $\gamma$ activators. Biochem. Biophys. Res. Commun. 2003, 300, 472-476. [CrossRef]

38. Park, H.K.; Kwak, M.K.; Kim, H.J.; Ahima, R.S. Linking resistin, inflammation, and cardiometabolic diseases. Korean J. Intern. Med. 2017, 32, 239-247. [CrossRef]

39. Park, H.K.; Qatanani, M.; Briggs, E.R.; Ahima, R.S.; Lazar, M.A. Inflammatory induction of human resistin causes insulin resistance in endotoxemic mice. Diabetes 2011, 60, 775-783. [CrossRef] [PubMed]

40. Heo, Y.J.; Choi, S.E.; Jeon, J.Y.; Han, S.J.; Kim, D.J.; Kang, Y.; Lee, K.W.; Kim, H.J. Visfatin Induces Inflammation and Insulin Resistance via the NF-kappaB and STAT3 Signaling Pathways in Hepatocytes. J. Diabetes Res. 2019, 2019, 4021623. [CrossRef]

41. Zhang, S.; Chen, Q.; Lin, X.; Chen, M.; Liu, Q. A Review of Adropin as the Medium of Dialogue between Energy Regulation and Immune Regulation. Oxid. Med. Cell. Longev. 2020, 2020, 3947806. [CrossRef]

42. Akcilar, R.; Emel Kocak, F.; Simsek, H.; Akcilar, A.; Bayat, Z.; Ece, E.; Kokdasgil, H. The effect of adropin on lipid and glucose metabolism in rats with hyperlipidemia. Iranian J. Basic Med. Sci. 2016, 19, 245-251.

43. Bozic, J.; Borovac, J.A.; Galic, T.; Kurir, T.T.; Supe-Domic, D.; Dogas, Z. Adropin and Inflammation Biomarker Levels in Male Patients With Obstructive Sleep Apnea: A Link With Glucose Metabolism and Sleep Parameters. J. Clin. Sleep Med. JCSM 2018, 14, 1109-1118. [CrossRef]

44. Banerjee, S.; Ghoshal, S.; Girardet, C.; DeMars, K.M.; Yang, C.; Niehoff, M.L.; Nguyen, A.D.; Jayanth, P.; Mersman, B.A.; Xu, F. Adropin expression correlates with age-related neuropathologies in the human brain and improves neuroinflammation and cognitive function in aging mice. Res. Sq. 2021. [CrossRef]

45. Ellulu, M.S.; Patimah, I.; Khaza'ai, H.; Rahmat, A.; Abed, Y. Obesity and inflammation: The linking mechanism and the complications. Arch. Med. Sci. AMS 2017, 13, 851-863. [CrossRef]

46. Lian, A.; Wu, K.; Liu, T.; Jiang, N.; Jiang, Q. Adropin induction of lipoprotein lipase expression in tilapia hepatocytes. J. Mol. Endocrinol. 2016, 56, 11-22. [CrossRef] [PubMed]

47. Carmen, G.Y.; Victor, S.M. Signalling mechanisms regulating lipolysis. Cell. Signal. 2006, 18, 401-408. [CrossRef] [PubMed] 